\title{
Effect of Magnetic Iron and Potassium Humate on Some Flowering and Fruiting Characteristics of "Aggizi" Olive Trees Grown under Salt Stress Conditions in South Sinai
}

\author{
M.G. Abo-Gabien*1, A. R. Atawia ${ }^{2}$, H. E. M. El-Badawy², S. F. El-Gioushy² and S. M. Bakeer ${ }^{1}$ \\ 1. Plant Production department, Desert Research center, Egypt. \\ 2. Horticulture Department, Faculty of Agriculture, Benha University, Egypt. \\ Corresponding author: mohamed.gomaa1997214@gmail.com
}

\begin{abstract}
The use of soil amelioration agents is an important physiological method that improves plant tolerance to salt stress. The aim of this research is to examine the soil application of magnetic iron (MI) and/or potassium humate $(\mathrm{KH})$ to mitigate the effect of salinity on the flowering and fruiting characteristics of 'Aggizi' olive trees. Tenyear-old trees grown in sandy loam soil were treated with four levels of MI $(0,500,750$ and $1000 \mathrm{~g} /$ tree $)$ and $\mathrm{KH}(0,50,75$ and $100 \mathrm{~g} /$ tree $)$ as a single dose during soil preparation on 1 December in both seasons. The result showed that the individual application of each anti-salt stress substance improved the flowering and fruiting characteristics and resulted in the higher number of inflorescence per shoot, fruit set percentage, fruit weight, fruit diameters, flesh thickness and tree yield compared to the control plants. The dual interaction of MI with KH was significant for all of the studied attributes. The interaction of the highest levels of MI (750 or $1000 \mathrm{~g}$ per tree) and KH (75 or $100 \mathrm{~g}$ per tree) improved the flowering and fruiting characteristics of "Aggizi "olive trees. These results suggest that anti-salt stress substances may be useful methods for use in arid and semi-arid regions to enhance salt tolerance in olives.
\end{abstract}

Keywords: Olive, Salinity, Magnetic iron, Potassium humate, Flowering and productivity aspects.

\section{Introduction}

Olive (Olea europaea L.) is an evergreen tree belonging to the Oleaceae family, which has been one of the oldest cultivated trees in the history of the world for thousands of years (Caponera, 1993). The olive tree is of great importance in Sinai, because it has cultural, traditional and economic value. 'Aggizi' (Aggizi shame) is the most widely cultivated table olive cultivar in Egypt.

Water used for irrigation in olive orchards is often saline water, especially in the coastal area of Southern Sinai. Generally, soils in South Sinai are usually deficient in fertility nutrients (especially micronutrients), very low in organic matter, alkaline (high $\mathrm{pH})$, high in calcium carbonate $\left(\mathrm{CaCO}_{3}\right)$ and high content of salinity.

In the arid and semi-arid regions, salinity is one of the most important abiotic stresses and a serious threat to agricultural sustainability. The extent of salinity problem is about $10 \%$ of world land area and $50 \%$ of irrigated areas which results in 12 billion US\$ loss of agricultural production (Flowers et al., 2010).

Salinity of irrigation water can cause a build-up of salts in the root zone, particularly if the internal drainage of the soils (or leaching by rainfall or applied irrigation) is inadequate. In some coastal areas, the extracting of groundwater has proceeded to the point where the intrusion of seawater into the aquifers has degraded the quality of these resources. Continued irrigation with such low-quality groundwater has contributed to the expansion of land salinization (Karajeh et al., 2013).

Many studies have focused on physiological aspects of salinity in plants (Long and Baker, 1986; Morales et al., 2008; Belkhodja et al., 1999; Abadı'a et al., 1999). Thus, plant growth (i.e., root and shoot length, total leaf area, and dry weight) is inhibited by moderate and high salinity (Marin et al., 1995; Tattini et al., 1995; Chartzoulakis et al., 2002; Vigo et al., 2005). Plants grown under $\mathrm{NaCl}$ salinity show an increase in sodium and chloride concentrations, and a decrease in potassium, calcium and magnesium (Bartolini et al., 1991; Tattini et al., 1995; Chartzoulakis et al., 2002; Vigo et al., 2002). Nutrient uptake by plants can be reduced by excessive salts in the soil solution, either by direct competition between ions or by increased osmotic potential of the solution reducing the mass flow of mineral nutrients to the root surface (Grattan and Grieve, 1999).

Therefore, since salinity is one of the increasing problems in the world and covers a large area of Egypt, it is necessary to study and develop physiological techniques to increase plant resistance to salt stress. Magnetite (magnetic iron) and potassium humate can be added to the soil as an ameliorative agent in order to overcome the negative effect of salinity (Abobatta, 2015).

One of the most useful factors in the plant growth is the enhancement of salinity tolerance by means of magnetite. Magnetite has a black or brownish-red color, a natural row rock with very high iron content, and a hardness of about six on the Mohs hardness scale. It is one of two naturally magnetic row rocks in the world (Mansour, 2011). The positive effect of magnetic therapy can be attributed to the paramagnetic properties of certain atoms in plant cells and certain pigments, such as chloroplasts. The magnetic properties of molecules influences their ability to attract and then change the magnetic field's energy to other energy types and to move it to other plant cell structures, thereby enabling them to be 
activated (Aladjadjiyan, 2002). Iron oxide minerals have the most reactive surface sites among inorganic minerals existing in the environment and are capable of binding natural inorganic and organic materials, including cations and anions. The electrostatic forces between metal ion and surface charge in the presence of $\mathrm{Fe}^{2+}$ of magnetite attributed to such an excellent adsorption behavior (Ahmed et al., 2013).

Potassium humate, as a natural organic macromolecular compound and environmentally friendly carbon resource, which derives from peat, brown coal or weathered coal, etc. possesses a wide variety of oxygen-containing functional groups and has good adsorption and complexation properties for many kinds of soil minerals. Many investigators reported that, application of humic substances led to a remarkable increment in soil organic matter and reduce the negative effect of salt stress, which improve plant growth and increase crop production (El-Hefny 2010 on cowpea Kirn et al 2010 and Gad El-Hak et al. 2012 on Peason garlic). Moreover, the application of potassium helps the plants to cope with the hazardous effects of salinity by improving the morphological, physiological and biochemical attributes.

Among various macronutrients, potassium $\left(\mathrm{K}^{+}\right)$ occupies an important role in the survival of plants under salt stressed conditions (Mengel, Kirkby, 2001; Mahmood, 2011).

Potassium humate was combined with magnetic iron to increase effective adsorption sites and hydroxyl groups showed a considerable adsorption capacity of $280.6 \mathrm{mg} / \mathrm{g}$ (Lei, et al., 2014; Gu et al., 2016). The most active surface sites (mainly $\mathrm{Fe}-\mathrm{OH}$ site on magnetite) are able to bind to humic acid in the soil (Illes and Tombacz 2006). HA has a skeleton of alkyl and aromatic units that attach with carboxylic acid, phenolic hydroxyl and quinone functional groups, which could have strong affinity to the surface of magnetite. The absorption of HA on magnetite generally enhances their stability through a combination of steric and electrostatic effects. Additionally, due to ligand exchange reactions between HA and the surface sites of iron oxide dissolved Fe (III) ions move into the aqueous phase from the surface of magnetite. Therefore, the bioavailable iron ions are increased in soil and would subsequently stimulate the growth of certain soil microbes. It has often been stated that they are active agents in the decomposition of organic matter, releasing carbon, nitrogen and ammonia, which supply plants with nutrients, and releasing cellobiose and various oligosaccharide intermediates as degradation products (Bahn et al. 1979). In addition to, magnetite amendments could facilitate the turnover of $\mathrm{C}$ and $\mathrm{N}$ in soil by stimulating soil enzymes such as invertase and urease (Jenkinson and Ladd, 1981).

However, according to the available literature there is no information about the effect of magnetite alone or in combination with potassium humate on flowering and fruiting attributes of olive trees under salinity stress conditions.

The aim objective of this study was to evaluate to what extent applications of magnetite, potassium humate and their interactions can play an important role in reducing the impact of salinity stress on'Aggizi' olive trees.

\section{Materials and methods}

\section{Orchard site and experimental design}

This investigation was conducted on olive trees orchard at South Sinai Experimental Station (Ras Sudr) a facility of the Desert Research Center of Egypt located at South Sinai Governorate. The study was carried out in two successive seasons (2017, 2018 2018, 2019). The cultivar 'Aggizi' olive used in this study was raised by semi hard wood cuttings. Ninetysix trees healthy, nearly uniform in shape, size, and productivity and received the same horticultural practices were selected as test plants. The selected trees were approximately 10 years old, grown in sandy loam soil, planted at a spacing of $5 \mathrm{~m} \times 5 \mathrm{~m}$ under a drip irrigation system to supply water from the artesian well. The physical and chemical properties of the soil in addition to irrigation water used in this study are presented in (Tables 1 and 2).

Table 1. Some physical and chemical properties of the experimental soil.

\begin{tabular}{|c|c|c|c|c|c|c|c|c|c|c|}
\hline \multicolumn{11}{|c|}{ Physical analysis } \\
\hline Soil depth (cm) & Silt \% & & \multicolumn{4}{|c|}{ Clay \% } & \multicolumn{4}{|c|}{ Texture class } \\
\hline $0-30$ & 8.05 & & \multicolumn{4}{|c|}{10.67} & \multicolumn{4}{|c|}{ Sand Loam } \\
\hline $30-60$ & 7.59 & & \multicolumn{4}{|c|}{6.33} & \multicolumn{4}{|c|}{ Sand Loam } \\
\hline \multicolumn{11}{|c|}{ Chemical analysis } \\
\hline \multirow[t]{2}{*}{ Soil depth (cm) } & \multirow[t]{2}{*}{ pH } & E.Ce $\left(\mathrm{dSm}^{-1}\right)$ & \multicolumn{4}{|c|}{ Soluble cations (mequiv/L) } & \multicolumn{4}{|c|}{ Soluble anions (mequiv/L) } \\
\hline & & & $\mathrm{Ca}++$ & Mg++ & $\mathrm{Na}+$ & K+ & $\mathrm{CO}_{3}{ }^{2-}$ & $\mathrm{HCO}_{3}{ }^{-}$ & $\mathrm{SO}_{4}{ }^{2-}$ & $\mathrm{Cl}^{-}$ \\
\hline $0-30$ & 7.97 & 9.06 & 16.32 & 6.99 & 66.30 & 0.99 & - & 5.00 & 4.60 & 81.00 \\
\hline $30-60$ & 8.05 & 3.94 & 10.61 & 1.63 & 26.61 & 0.55 & - & 3.00 & 12.40 & 24.00 \\
\hline
\end{tabular}

Table (2): Some chemical properties of the irrigation water. 


\begin{tabular}{|c|c|c|c|c|c|c|c|c|c|}
\hline \multirow[t]{2}{*}{ pH } & \multirow[t]{2}{*}{ E.C. $\left(\mathrm{dSm}^{-1}\right)$} & \multicolumn{4}{|c|}{ Soluble cations (mequiv./L) } & \multicolumn{4}{|c|}{ Soluble anions (mequiv./L) } \\
\hline & & $\mathrm{Ca}^{2+}$ & $\mathbf{M g}^{2+}$ & $\mathrm{Na}^{+}$ & $\mathbf{K}^{+}$ & $\mathrm{CO}_{3}{ }^{2-}$ & $\mathrm{HCO}_{3}{ }^{-}$ & $\mathrm{SO}_{4}{ }^{2-}$ & $\mathrm{Cl}^{-}$ \\
\hline 7.22 & 9.19 & 13.98 & 6.52 & 70.92 & 0.48 & - & 4.40 & 32.20 & 3.57 \\
\hline
\end{tabular}

The experimental design was a factorial between magnetic iron applications (four levels) and potassium humate (four levels) in a completely randomized block design with three replicates for each treatment and two trees for each replicate. The four magnetic iron levels were $0,500,750$ and $1000 \mathrm{~g} /$ tree while the four potassium humate rates were $0,50,75$ and 100 $\mathrm{g} /$ tree. Both magnetic iron and potassium humate were applied round the trees as a single dose at the levels indicated above during soil preparation on $1^{\text {st }}$ December in both seasons. Magnetic iron was contained $48.8 \% \mathrm{Fe}_{3} \mathrm{O}_{4}, 17.3 \% \mathrm{Fe} \mathrm{O}, 26.7 \% \mathrm{Fe}_{2} \mathrm{O}_{3}$, $2.6 \% \mathrm{MgO}, 4.3 \% \mathrm{SiO}_{2}$ and $0.3 \% \mathrm{CaO}$, obtained from "El-Ahram Company", El Talbia, Faisal St. El-Giza Governorate. Potassium humate used in this study produced by Leili Agrochemistry Co., LTD, China and its properties are shown in (Table 3).

Table (3): Guaranteed analysis and physical data of Humic total

\begin{tabular}{lc}
\hline & Guaranteed analysis \\
\hline Humic acid & $80 \%$ \\
Potassium(K2) & $10-12 \%$ \\
Zn, Fe, Mn, etc., & $100 \mathrm{ppm}$ \\
\hline & Physical Data \\
\hline Appearance & Black powder \\
pH & $9-10$ \\
Water solubility & $<98 \%$ \\
\hline
\end{tabular}

Response of'Aggizi' olive trees to the tested treatments was evaluated through the following determinations.

\section{Flowering and fruiting characteristics}

\section{Flowering characteristics}

Flowering was evaluated on marked shoots, which remained on the tree throughout the experiment. Twenty flowering shoots were marked per tree, on which inflorescence number, flower number per inflorescence and number of axes per inflorescence were determined prior to bloom, and fruit number determined when fruit set was final. This information was also used to estimate percentage of fruits dropped on the ground in June during both seasons. Samples of ten inflorescences from each tree were taken at full bloom stage, avoiding marked shoots. Full bloom was defined according to (Rapoport and Rallo, 1991), as the day on which more than $50 \%$ of flowers were open on more than $50 \%$ of the branches. Flowers within each inflorescence were examined and the count of perfect flowers to the total number of flowers was calculated.

\section{Yield and fruit characteristics}

At maturity stage, each tree was manually harvested and the weight of total yield $(\mathrm{kg})$ for each individual tree was recorded in the two seasons. For fruit quality, 50 fruits from each tree were randomly picked to determine fruit weight $(\mathrm{g})$, flesh thickness $(\mathrm{cm})$, fruit length $(\mathrm{cm})$ and fruit diameter $(\mathrm{cm})$.

\section{Fruit oil content $(\%)$}

Olives were grinded in a mortar and then dried at $70{ }^{\circ} \mathrm{C}$ in a ventilated oven until a constant weight was measured in two successive weighing measurements. The oil content was determined by extracting the oil from the dried olive paste sample by means of Soxhlat fat extraction apparatus, using petroleum ether (60$80^{\circ} \mathrm{C}$ boiling point) as reported in the (A.O.A.C., 1990).

\section{Statistical analysis}

Data recorded during both seasons were subjected to analysis of variance (ANOVA) according to Snedecor and Cochran (1980) using by MSTAT-C software. Duncan multiple rang tests at level of $5 \%$ were used to differentiate means (Duncan 1955).

\section{Results}

\section{Flowering parameters}

\section{Number of inflorescence per shoot}

It is quite clear from Table (4) that treating "Aggizi" olive trees with magnetic iron at $750 \mathrm{~g}$ per tree increased significantly the number of inflorescence per shoot, followed by magnetic iron at $1000 \mathrm{~g}$ per tree compared to the control treatment.

Moreover, the number of inflorescence per shoot increased linearly by increasing amount of potassium humate. The highest number of inflorescence per shoot was scored with potassium humate at $100 \mathrm{~g}$ per tree. On the other hand, the lowest value was found with those untreated trees (control).

However, magnetic iron at $750 \mathrm{~g}$ per tree combined with either 75 or $100 \mathrm{~g}$ per tree of potassium humate induced highly significant improvement in the number of inflorescence per shoot in both seasons. On the other way around, the least value of number of inflorescence per shoot was recorded with the trees which were not received any of the two investigated anti-salt stress substances.

\section{Number of flowers per inflorescence}

Data in Table (4) indicate that both of the treated trees with magnetic iron at 750 and $1000 \mathrm{~g}$ per tree enhanced obviously the number of flowers per inflorescence. On the other hand, untreated trees had given the least number of flowers per inflorescence in both seasons. 
Furthermore, the highest number of flowers per inflorescence was obtained by soil application of potassium humate at $75 \mathrm{~g}$ per tree followed by $100 \mathrm{~g}$ per tree in both seasons. While, the lowest number of flowers per inflorescence was obtained with the control treatment in both seasons of study.

Nevertheless, the combination of magnetic iron at $750 \mathrm{~g}$ per tree and potassium humate at $75 \mathrm{~g}$ per tree produced the highest number of flowers per inflorescence during the two seasons under study. On the other hand, the least value of number of flowers per inflorescence was observed when the "Aggizi "olive trees were not received neither magnetic iron nor potassium humate.

Table (4): Effect of magnetic iron (MI), potassium humate (KH) and their interactions on number of inflorescence per shoot and number of flowers per inflorescence of "Aggizi "olive trees grown under salt stress conditions in 2017/018 and 2018/019 seasons.

\begin{tabular}{|c|c|c|c|c|c|c|c|c|c|c|}
\hline \multirow{3}{*}{$\begin{array}{l}\text { Magnetic } \\
\text { iron } \\
\text { treatments } \\
\text { (g/tree) }\end{array}$} & \multicolumn{5}{|c|}{$2017 / 2018$} & \multicolumn{5}{|c|}{ 2018/2019 } \\
\hline & \multicolumn{10}{|c|}{ Potassium humate treatments $(\mathrm{g} /$ tree $)$} \\
\hline & $\mathbf{0}$ & 50 & 75 & 100 & Mean & $\mathbf{0}$ & 50 & 75 & 100 & Mean \\
\hline \multicolumn{11}{|c|}{ Number of inflorescence per shoot } \\
\hline 0 & $4.33 \mathrm{j}$ & $5.66 \mathrm{i}$ & $7.50 \mathrm{~h}$ & $8.66 \mathrm{fgh}$ & $6.54 \mathrm{C}$ & $6.66 \mathrm{~h}$ & $8.00 \mathrm{~g}$ & $10.16 \mathrm{f}$ & $11.1 \mathrm{def}$ & $9.00 \mathrm{C}$ \\
\hline 500 & $8.16 \mathrm{gh}$ & 9.66def & $9.00 \mathrm{efg}$ & $10.16 \mathrm{cde}$ & 9.25B & $10.50 \mathrm{ef}$ & $12.00 \mathrm{~d}$ & 11.def & $12.50 \mathrm{~cd}$ & 11.62B \\
\hline 750 & 8.33 efg & $11.16 \mathrm{abc}$ & $11.83 \mathrm{ab}$ & $12.00 \mathrm{a}$ & 11.08A & 11.66de & $13.50 \mathrm{~b}$ & $15.00 \mathrm{ab}$ & $16.50 \mathrm{a}$ & 14.17A \\
\hline 1000 & $10.00 \mathrm{cde}$ & $10.00 \mathrm{cde}$ & $10.66 \mathrm{bcd}$ & $12.33 \mathrm{a}$ & $10.75 \mathrm{~A}$ & $12.5 \mathrm{~cd}$ & $12.5 \mathrm{~cd}$ & $13.5 \mathrm{bc}$ & $15.00 \mathrm{ab}$ & 13.66A \\
\hline Mean & $7.95 \mathrm{D}$ & $9.12 \mathrm{C}$ & $9.75 B$ & 10.79A & & 10.33D & 11.50C & 13.54B & 13.29A & \\
\hline \multicolumn{11}{|c|}{ Number of flowers per inflorescence } \\
\hline $\mathbf{0}$ & $8.33 \mathrm{~h}$ & $9.50 \mathrm{gh}$ & $10.50 \mathrm{defg}$ & $11.00 \mathrm{cdef}$ & $9.83 \mathrm{C}$ & $10.66 \mathrm{~g}$ & $11.83 \mathrm{f}$ & $12.66 \mathrm{ef}$ & $13.66 \mathrm{cde}$ & $12.20 \mathrm{C}^{\prime}$ \\
\hline 500 & $9.67 \mathrm{fgh}$ & $11.67 \mathrm{bcd}$ & $11.67 \mathrm{bcd}$ & 11.17bcde & 11.04B & $12.00 \mathrm{f}$ & $13.83 \mathrm{bcd}$ & $14.16 \mathrm{bc}$ & $13.66 \mathrm{~cd}$ & 13.41B \\
\hline 750 & $10.00 \mathrm{efg}$ & $12.33 \mathrm{abc}$ & $13.50 \mathrm{a}$ & $12.33 \mathrm{abc}$ & $12.04 \mathrm{~A}$ & $12.00 \mathrm{f}$ & $14.50 \mathrm{bc}$ & $15.66 \mathrm{a}$ & $14.66 \mathrm{ab}$ & $14.20 \mathrm{~A}$ \\
\hline 1000 & $10.83 \mathrm{defg}$ & $12.17 \mathrm{abc}$ & $12.17 \mathrm{abc}$ & $12.50 \mathrm{ab}$ & $11.92 \mathrm{~A}$ & 13.16de & $14.33 \mathrm{bc}$ & $14.33 \mathrm{bc}$ & $14.66 \mathrm{ab}$ & 14.12A \\
\hline Mean & 9.71B & $11.42 \mathrm{~A}$ & $11.96 \mathrm{~A}$ & $11.75 \mathrm{~A}$ & & $11.95 \mathrm{C}$ & 13.62 B & $14.20 \mathrm{~A}$ & 14.16A & \\
\hline
\end{tabular}

Values within column and row for any of two investigated factors were individually differentiated by capital letters, while for the interaction small letters were used. Means followed by the same letters were not significantly different at $5 \%$ level.

\section{Number of axes per inflorescence}

Data in Table (5) refer that the higher dose $1000 \mathrm{~g}$ per tree of magnetic iron recorded the maximum number of axes per inflorescence, followed by magnetic iron dose at $750 \mathrm{~g}$ per tree, as compared with untreated trees, which reflect the least value of the investigated parameter in both seasons.

In addition, the maximum number of axes per inflorescence was detected with the addition of potassium humate at 75 or $100 \mathrm{~g}$ per tree in both seasons, respectively, as compared with control treatment.

Moreover, the combination between $750 \mathrm{~g}$ per tree of magnetic iron and $75 \mathrm{~g}$ per tree of potassium humate was the superior one as it maximized the investigated parameter as compared with the other combinations. Meanwhile, the least value was detected with those untreated trees with neither one of the two investigated substances.

Table (5): Effect of magnetic iron (MI), potassium humate $(\mathrm{KH})$ and their interactions on number of axes per inflorescence and perfect flowers percentage of "Aggizi "olive trees grown under salt stress conditions in 2017/018 and 2018/019 seasons.

\begin{tabular}{|c|c|c|c|c|c|c|c|c|c|c|}
\hline \multirow{3}{*}{$\begin{array}{l}\text { Magnetic } \\
\text { iron } \\
\text { treatments } \\
(\mathrm{g} / \text { tree })\end{array}$} & \multicolumn{5}{|c|}{$2017 / 2018$} & \multicolumn{5}{|c|}{ 2018/2019 } \\
\hline & \multicolumn{10}{|c|}{ Potassium humate treatments $(\mathrm{g} /$ tree) } \\
\hline & $\mathbf{0}$ & $\mathbf{5 0}$ & 75 & 100 & Mean & $\mathbf{0}$ & $\mathbf{5 0}$ & 75 & 100 & Mean \\
\hline \multicolumn{11}{|c|}{ Number of axes per inflorescence } \\
\hline 0 & $4.66 \mathrm{~g}$ & $5.50 \mathrm{def}$ & $5.33 \mathrm{ef}$ & 6.00abcd & $5.37 \mathrm{~B}$ & $4.83 \mathrm{~d}$ & $6.00 \mathrm{bc}$ & $6.00 \mathrm{bc}$ & $6.50 \mathrm{ab}$ & $5.83 \mathrm{C}$ \\
\hline 500 & $5.16 \mathrm{fg}$ & $5.66 \mathrm{cdef}$ & 5.83bcde & $5.50 \mathrm{def}$ & $5.54 \mathrm{~B}$ & $5.66 \mathrm{c}$ & $6.16 \mathrm{abc}$ & 6.33abc & $6.00 \mathrm{bc}$ & $6.04 B C$ \\
\hline 750 & $5.50 \mathrm{def}$ & $5.83 \mathrm{bcde}$ & $6.50 \mathrm{a}$ & $5.83 \mathrm{bcde}$ & $5.91 \mathrm{~A}$ & $6.00 \mathrm{bc}$ & $6.33 \mathrm{abc}$ & $6.83 \mathrm{a}$ & $6.33 \mathrm{abc}$ & 6.37AB \\
\hline 1000 & $5.50 \mathrm{def}$ & 5.83bcde & $6.33 \mathrm{ab}$ & $6.16 \mathrm{abc}$ & $5.95 \mathrm{~A}$ & $6.16 \mathrm{abc}$ & $6.33 \mathrm{abc}$ & $6.83 \mathrm{a}$ & $6.66 \mathrm{ab}$ & $6.50 \mathrm{~A}$ \\
\hline Mean & $5.20 \mathrm{C}$ & $5.70 \mathrm{~B}$ & $6.00 \mathrm{~A}$ & $5.87 \mathrm{AB}$ & & $5.66 \mathrm{~B}$ & $6.20 \mathrm{~A}$ & $6.50 \mathrm{~A}$ & $6.37 \mathrm{~A}$ & \\
\hline \multicolumn{11}{|c|}{ Perfect flowers percentage $\%$} \\
\hline $\mathbf{0}$ & $52.33 \mathrm{i}$ & $56.0 \mathrm{~h}$ & 60.83 & $62 . \mathrm{fg}$ & 57.79C & $51.00 \mathrm{i}$ & $57.50 \mathrm{~h}$ & $62.33 \mathrm{~g}$ & $62.8 \mathrm{fg}$ & 58.41C \\
\hline 500 & $59.33 \mathrm{gh}$ & 63.16de & 64.0def & $63.50 \mathrm{def}$ & $62.50 \mathrm{~B}$ & $60.16 \mathrm{gh}$ & 64.16def & $64.50 \mathrm{def}$ & $64.00 \mathrm{def}$ & $63.20 \mathrm{~B}$ \\
\hline 750 & $61.33 \mathrm{fg}$ & $65.16 \mathrm{de}$ & $69.66 \mathrm{a}$ & $67.50 \mathrm{bc}$ & $65.91 \mathrm{~A}$ & $62.00 \mathrm{fg}$ & $65.33 \mathrm{de}$ & $71.00 \mathrm{a}$ & $68.00 \mathrm{bc}$ & $66.58 \mathrm{~A}$ \\
\hline 1000 & $65.16 \mathrm{~cd}$ & $65.16 \mathrm{~cd}$ & $68.83 \mathrm{ab}$ & $68.3 b$ & $67.37 \mathrm{~A}$ & $66.16 \mathrm{~cd}$ & $65.83 \mathrm{~d}$ & $69.66 \mathrm{~b}$ & $70.83 b$ & $68.12 \mathrm{~A}$ \\
\hline Mean & $59.5 \mathrm{C}$ & $62.7 \mathrm{~B}$ & 65.3A & $65.8 \mathrm{~A}$ & & $59.83 \mathrm{C}$ & $63.2 B$ & $66.8 \mathrm{~A}$ & $66.4 \mathrm{~A}$ & \\
\hline
\end{tabular}

Values within column and row for any of two investigated factors were individually differentiated by capital letters, while for the interaction small letters were used. Means followed by the same letters were not significantly different at $5 \%$ level. 


\section{Perfect flowers percentage}

The data presented in Table (5) indicate that the addition of either 750 or $1000 \mathrm{~g}$ of magnetic iron per tree had a statistically similar effect on the percentage of perfect flowers. Nevertheless, control treatment has proven to be the least effective in both seasons in this regard.

However, the addition of potassium humate at either 75 or $100 \mathrm{~g}$ per tree caused highly significant improvement in percentage of perfect flowers, followed by the lower level of this investigated factor, as compared with untreated trees, which reflect the least value of the studied parameter.

Furthermore, the highest value of the investigated parameter was detected with the combination between magnetic iron at $750 \mathrm{~g}$ per tree and potassium humate at $75 \mathrm{~g}$ per tree. Meanwhile, the least value was detected with the trees, which did not receive any of both factors.

\section{Fruit set percentage $(\%)$}

Data presented in Table (6) reflect that fruit set percentage was highly improved with increasing the dose of magnetic iron, i.e. the higher dose (1000 g per tree) of magnetic iron was better than the lower dose (750 g per tree). Furthermore, the least value of fruit set percentage was recorded with untreated trees.

In addition, the highest significant value of fruit set percentage was obtained when the trees treated with potassium humate at a rate of $100 \mathrm{~g}$ per tree, followed by $75 \mathrm{~g}$ per tree as compared with control treatment.

Moreover, the combination between the higher dose of both $(1000 \mathrm{~g}$ per tree of magnetic iron $+100 \mathrm{~g}$ per tree of potassium humate) was the superior one as it maximized the investigated parameter as compared with the other combinations. Meanwhile, the least value was detected with those untreated trees with neither one of the two investigated substances.

Table (6): Effect of magnetic iron (MI), potassium humate $(\mathrm{KH})$ and their interactions on fruit set percentage and June fruit drop percentage of "Aggizi "olive trees grown under salt stress conditions in 2017/018 and 2018/019 seasons.

\begin{tabular}{|c|c|c|c|c|c|c|c|c|c|c|}
\hline \multirow{3}{*}{$\begin{array}{l}\text { Magnetic iron } \\
\text { treatments } \\
\text { (g/tree) }\end{array}$} & \multicolumn{5}{|c|}{$2017 / 2018$} & \multicolumn{5}{|c|}{ 2018/2019 } \\
\hline & \multicolumn{10}{|c|}{ Potassium humate treatments (g/tree) } \\
\hline & $\mathbf{0}$ & 50 & 75 & 100 & Mean & $\mathbf{0}$ & $\mathbf{5 0}$ & 75 & 100 & Mean \\
\hline \multicolumn{11}{|l|}{ Fruit set (\%) } \\
\hline $\mathbf{0}$ & $2.21 \mathrm{i}$ & $2.81 \mathrm{gh}$ & 3.06efg & $3.47 \mathrm{~cd}$ & 2.89D & $2.16 \mathrm{j}$ & $3.20 \mathrm{ghi}$ & $3.33 \mathrm{fgh}$ & $3.67 \mathrm{bcde}$ & 3.09D \\
\hline 500 & $2.61 \mathrm{~h}$ & $2.92 \mathrm{fgh}$ & $3.35 \mathrm{de}$ & $3.56 \mathrm{bcd}$ & 3.11C & $2.92 \mathrm{i}$ & $3.25 \mathrm{fgh}$ & 3.50def & $3.71 \mathrm{bd}$ & $3.35 \mathrm{C}$ \\
\hline 750 & $2.85 \mathrm{fgh}$ & $3.56 \mathrm{bcd}$ & $3.69 \mathrm{bc}$ & $3.76 \mathrm{abc}$ & 3.46B & $3.10 \mathrm{hi}$ & $3.65 \mathrm{cde}$ & $3.78 \mathrm{bcd}$ & $3.96 a b$ & 3.62B \\
\hline 1000 & $3.15 \mathrm{ef}$ & $3.78 \mathrm{ab}$ & 3.72abc & $4.01 \mathrm{a}$ & 3.66A & $3.41 \mathrm{efg}$ & $3.95 \mathrm{abc}$ & $3.96 \mathrm{ab}$ & $4.13 \mathrm{a}$ & $3.86 \mathrm{~A}$ \\
\hline Mean & 2.70D & $3.27 \mathrm{C}$ & 3.46B & $3.70 \mathrm{~A}$ & & $2.90 \mathrm{C}$ & $3.51 \mathrm{~B}$ & 3.64B & 3.87A & \\
\hline \multicolumn{11}{|c|}{ June fruit drop (\%) } \\
\hline $\mathbf{0}$ & $16.33 \mathrm{a}$ & $13.50 \mathrm{~b}$ & $9.00 \mathrm{de}$ & $5.83 \mathrm{fg}$ & 11.16A & $17.50 \mathrm{a}$ & $13.00 \mathrm{~b}$ & $8.50 \mathrm{de}$ & $5.16 \mathrm{fgh}$ & 11.04A \\
\hline 500 & $14.16 \mathrm{ab}$ & $11.66 \mathrm{bcd}$ & $7.66 \mathrm{ef}$ & $5.16 \mathrm{fg}$ & $9.66 \mathrm{~A}$ & $12.34 \mathrm{bc}$ & $10.50 \mathrm{~cd}$ & $6.66 \mathrm{ef}$ & 4.50ghi & $8.50 \mathrm{~B}$ \\
\hline 750 & $12.33 \mathrm{bc}$ & $9.16 \mathrm{de}$ & $4.33 \mathrm{~g}$ & $4.66 \mathrm{~g}$ & 7.62B & $11.00 \mathrm{bc}$ & 4.58fghi & $3.75 \mathrm{hi}$ & 4.16hi & $5.87 \mathrm{C}$ \\
\hline 1000 & $9.66 \mathrm{cde}$ & $8.00 \mathrm{ef}$ & $3.80 \mathrm{~g}$ & $3.08 \mathrm{~g}$ & $6.13 B$ & 8.66de & $6.33 \mathrm{fg}$ & 3.33hi & $3.03 \mathrm{i}$ & $5.3 \mathrm{C}$ \\
\hline Mean & 13.12A & $10.58 \mathrm{~B}$ & $6.20 \mathrm{C}$ & 4.68D & & 12.37A & $8.60 \mathrm{~B}$ & $5.56 \mathrm{C}$ & 4.21D & \\
\hline
\end{tabular}

Values within column and row for any of two investigated factors were individually differentiated by capital letters, while for the interaction small letters were used. Means followed by the same letters were not significantly different at $5 \%$ level.

\section{June fruit drop percentage $(\%)$}

Data presented in Table (6) refer that treated trees either at 750 or $1000 \mathrm{~g}$ per tree of magnetic iron led to reduce of June fruit drop ratio in both seasons. On the other hand, untreated trees gave the highest values in this respect.

Furthermore, fruit drop ratio was decreased significantly by increasing potassium humate rate, which reached to the minimum values with the treatment of $100 \mathrm{~g}$ per tree of potassium humate in comparison with control treatment in both seasons.

Moreover, the combination of the higher magnetic iron level (1000 g per tree) and the higher potassium humate level (100 g per tree) has led to a lower fruit drop ratio. Meanwhile, the reverse was true of treated trees with neither of the two factors.

\section{Total yield (kg/tree)}

Data tabulated in Table (7) showed that the addition of magnetic iron either at 1000 or $750 \mathrm{~g}$ per tree were effective in this respect, as the two abovementioned levels significantly increased the yield of tree during both seasons of study. On the other hand, the least value of gained yield was gotten with untreated trees.

Moreover, the maximum yield value was detected with addition of the higher level of potassium humate (100 g per tree) during both seasons of study. On the other hand, the least value of tree yield was noticed with those untreated trees (control).

Furthermore, the maximum yield value was recorded with the combination between magnetic iron at $1000 \mathrm{~g}$ per tree and potassium humate at $100 \mathrm{~g}$ per tree. Meanwhile, the least yield value was recorded with the trees that did not receive any of both factors. 
Fruit oil percentage $(\% \mathrm{dw})$

Data shown in Table (7) reflect that all magnetic iron treatments succeeded in improving fruit oil percentage compared with the control treatment.

In addition, the best results were for oil olive with potassium humate either at 100 or at $75 \mathrm{~g}$ per tree compared to the control in both seasons.
The combination of magnetic iron at $750 \mathrm{~g}$ per tree and potassium humate at $75 \mathrm{~g}$ per tree recorded the highest percentage in olive oil. Meanwhile, the lowest percentage of oil in "Aggizi" olive cultivar obtained with trees that did not receive any transactions during the study seasons.

Table (7): Effect of magnetic iron (MI), potassium humate $(\mathrm{KH})$ and their interactions on total yield and fruit oil percentage of "Aggizi "olive trees grown under salt stress conditions in 2017/018 and 2018/019 seasons.

\begin{tabular}{|c|c|c|c|c|c|c|c|c|c|c|}
\hline \multirow{3}{*}{$\begin{array}{l}\text { Magnetic } \\
\text { iron } \\
\text { treatments } \\
\text { (g/tree) }\end{array}$} & \multicolumn{5}{|c|}{$2017 / 2018$} & \multicolumn{5}{|c|}{$2018 / 2019$} \\
\hline & \multicolumn{10}{|c|}{ Potassium humate treatments (g/tree) } \\
\hline & $\mathbf{0}$ & 50 & 75 & 100 & Mean & $\mathbf{0}$ & 50 & 75 & 100 & Mean \\
\hline \multicolumn{11}{|c|}{ Total yield (kg/ tree) } \\
\hline 0 & $7.79 \mathrm{k}$ & $9.75 \mathrm{j}$ & 12.15hi & $13.88 \mathrm{fg}$ & $10.89 \mathrm{C}$ & $11.83 \mathrm{~g}$ & $15.66 \mathrm{f}$ & $17.66 \mathrm{cdef}$ & $17.41 \mathrm{cdef}$ & 15.64C \\
\hline 500 & $10.76 \mathrm{ij}$ & $13.89 \mathrm{fg}$ & $14.51 \mathrm{ef}$ & $15.08 \mathrm{cde}$ & $13.56 \mathrm{~B}$ & $17.50 \mathrm{cdef}$ & 17.16def & $19.25 \mathrm{bcde}$ & $20.08 \mathrm{bc}$ & $18.50 \mathrm{~B}$ \\
\hline 750 & $12.98 \mathrm{gh}$ & $15.55 \mathrm{cde}$ & $17.50 \mathrm{~b}$ & $16.51 \mathrm{bc}$ & $15.63 \mathrm{~A}$ & $16.500 \mathrm{ef}$ & $20.50 \mathrm{bc}$ & $22.16 \mathrm{~b}$ & $22.33 b$ & 20.37A \\
\hline 1000 & $13.75 \mathrm{fg}$ & $14.63 \mathrm{def}$ & $16.05 \mathrm{bcd}$ & $19.50 \mathrm{a}$ & $15.98 \mathrm{~A}$ & $18.41 \mathrm{cdef}$ & $19.66 \mathrm{bcd}$ & $22.00 \mathrm{~b}$ & $27.33 \mathrm{a}$ & $21.85 A$ \\
\hline Mean & 11.32D & 13.45C & $15.05 B$ & $16.24 \mathrm{~A}$ & & 16.06D & $18.25 \mathrm{C}$ & 20.27B & 21.79A & \\
\hline \multicolumn{11}{|c|}{ Fruit oil percentage (dw\%) } \\
\hline 0 & $13.66 \mathrm{~h}$ & $14.28 \mathrm{gh}$ & $15.92 \mathrm{de}$ & $15.00 \mathrm{fg}$ & 14.72B & $12.33 \mathrm{f}$ & $13.60 \mathrm{ef}$ & $14.61 \mathrm{~cd}$ & $14.93 \mathrm{~cd}$ & 13.87B \\
\hline 500 & $17.72 \mathrm{ab}$ & $18.53 \mathrm{ab}$ & $18.63 \mathrm{abc}$ & $17.29 \mathrm{bc}$ & $18.04 \mathrm{~A}$ & $15.93 \mathrm{bc}$ & $17.70 \mathrm{ab}$ & $16.67 \mathrm{ab}$ & $16.96 \mathrm{ab}$ & $16.82 \mathrm{~A}$ \\
\hline 750 & $17.19 b c$ & $16.44 \mathrm{~cd}$ & $19.80 \mathrm{a}$ & $18.17 \mathrm{ab}$ & 17.90A & $15.07 \mathrm{~cd}$ & $13.70 \mathrm{ef}$ & $18.54 \mathrm{a}$ & $17.08 \mathrm{ab}$ & $16.10 \mathrm{~A}$ \\
\hline 1000 & $15.50 \mathrm{ef}$ & $16.05 \mathrm{de}$ & $17.72 \mathrm{ab}$ & $18.83 \mathrm{ab}$ & $17.02 \mathrm{~A}$ & $14.39 \mathrm{de}$ & $16.18 \mathrm{ab}$ & $16.66 \mathrm{ab}$ & $17.68 \mathrm{ab}$ & $16.23 \mathrm{~A}$ \\
\hline Mean & $16.02 \mathrm{C}$ & $16.32 B C$ & 18.02A & $17.32 \mathrm{AB}$ & & $14.43 B$ & 15.30B & $16.62 \mathrm{~A}$ & $16.66 \mathrm{~A}$ & \\
\hline
\end{tabular}

Values within column and row for any of two investigated factors were individually differentiated by capital letters, while for the interaction small letters were used. Means followed by the same letters were not significantly different at $5 \%$ level.

\section{Fruit quality parameters}

Fruit weight (g)

Data tabulated in Table (8) showed that the addition of magnetic iron either at 1000 or $750 \mathrm{~g}$ per tree were effective in this respect, as the two above mentioned levels increased the fruit weight during both seasons of study. On the other hand, the least value of fruit weight was detected with control treatment.
In addition, the maximum fruit weight value was detected with addition of potassium humate either at 100 or at $75 \mathrm{~g}$ per tree during both seasons of study. On the other hand, the least value of fruit weight was noticed with those untreated trees (control).

Moreover, the maximum fruit weight value was recorded with the combination between magnetic iron at a rate of $750 \mathrm{~g}$ per tree and potassium humate at a rate of $75 \mathrm{~g}$ per tree. Meanwhile, the least fruit weight value was recorded with the trees that did not receive any of both factors.

Table (8): Effect of magnetic iron (MI), potassium humate $(\mathrm{KH})$ and their interactions on fruit weight and flesh thickness of "Aggizi "olive trees grown under salt stress conditions in 2017/018 and 2018/019 seasons.

\begin{tabular}{|c|c|c|c|c|c|c|c|c|c|c|}
\hline \multirow{3}{*}{$\begin{array}{l}\text { Magnetic iron } \\
\text { treatments } \\
\text { (g/tree) }\end{array}$} & \multicolumn{5}{|c|}{$2017 / 2018$} & \multicolumn{5}{|c|}{ 2018/2019 } \\
\hline & \multicolumn{10}{|c|}{ Potassium humate treatments (g/tree) } \\
\hline & $\mathbf{0}$ & $\mathbf{5 0}$ & 75 & 100 & Mean & $\mathbf{0}$ & 50 & 75 & 100 & Mean \\
\hline \multicolumn{11}{|l|}{ Fruit weight $(\mathrm{g})$} \\
\hline 0 & $7.21 \mathrm{i}$ & $8.05 \mathrm{~h}$ & $8.73 \mathrm{~g}$ & $9.26 \mathrm{ef}$ & $8.32 \mathrm{C}$ & $7.46 \mathrm{e}$ & $8.48 \mathrm{~d}$ & $9.50 \mathrm{ab}$ & $9.65 \mathrm{~cd}$ & $8.52 \mathrm{~B}$ \\
\hline 500 & $8.80 \mathrm{~g}$ & $8.80 \mathrm{~g}$ & $8.80 \mathrm{~g}$ & $8.80 \mathrm{~g}$ & $8.80 \mathrm{~B}$ & $8.50 \mathrm{~d}$ & $8.41 \mathrm{~d}$ & 9.70ab & $9.93 \mathrm{bcd}$ & $8.88 \mathrm{~A}$ \\
\hline 750 & $8.95 \mathrm{fg}$ & $9.46 \mathrm{cde}$ & $10.28 \mathrm{a}$ & $9.80 \mathrm{bc}$ & $9.63 \mathrm{~A}$ & $8.40 \mathrm{~d}$ & $8.73 \mathrm{~cd}$ & $10.00 \mathrm{a}$ & $9.23 \mathrm{abc}$ & 9.09A \\
\hline 1000 & $9.36 \mathrm{de}$ & $9.55 \mathrm{cde}$ & $9.68 \mathrm{~cd}$ & $10.18 \mathrm{ab}$ & $9.70 \mathrm{~A}$ & $8.53 \mathrm{~d}$ & $8.83 \mathrm{~cd}$ & $9.20 \mathrm{abcd}$ & $9.91 \mathrm{a}$ & $9.12 \mathrm{~A}$ \\
\hline Mean & $8.58 \mathrm{C}$ & $8.96 B$ & 9.37A & $9.51 \mathrm{~A}$ & & $8.22 \mathrm{~B}$ & $8.61 B$ & $9.60 \mathrm{~A}$ & $9.18 \mathrm{~A}$ & \\
\hline \multicolumn{11}{|c|}{ Flesh thickness $(\mathrm{cm})$} \\
\hline 0 & $0.33 \mathrm{~h}$ & $0.38 \mathrm{~g}$ & $0.42 \mathrm{f}$ & $0.44 \mathrm{ef}$ & 0.39D & $0.31 \mathrm{f}$ & $0.37 \mathrm{e}$ & $0.42 \mathrm{~d}$ & $0.43 \mathrm{~cd}$ & $0.38 D$ \\
\hline 500 & $0.42 \mathrm{f}$ & $0.44 \mathrm{def}$ & $0.44 \mathrm{ef}$ & $0.46 \mathrm{de}$ & $0.44 C$ & $0.38 \mathrm{e}$ & $0.43 \mathrm{~cd}$ & $0.44 \mathrm{~cd}$ & $0.43 \mathrm{~cd}$ & $0.42 \mathrm{C}$ \\
\hline 750 & $0.47 \mathrm{~d}$ & $0.51 \mathrm{c}$ & $0.56 \mathrm{a}$ & $0.53 \mathrm{abc}$ & $0.52 B$ & $0.44 \mathrm{c}$ & $0.51 \mathrm{~b}$ & $0.55 \mathrm{a}$ & $0.52 b$ & $0.51 B$ \\
\hline 1000 & $0.52 b c$ & $0.54 \mathrm{ab}$ & $0.54 \mathrm{ab}$ & $0.53 b c$ & $0.54 \mathrm{~A}$ & $0.51 b$ & $0.52 \mathrm{~b}$ & $0.52 b$ & $0.52 b$ & $0.52 \mathrm{~A}$ \\
\hline Mean & $0.44 \mathrm{C}$ & $0.47 \mathrm{~B}$ & $0.49 \mathrm{~A}$ & $0.49 \mathrm{~A}$ & & $0.41 \mathrm{C}$ & $0.46 B$ & $0.48 \mathrm{~A}$ & $0.48 \mathrm{~A}$ & \\
\hline
\end{tabular}

Values within column and row for any of two investigated factors were individually differentiated by capital letters, while for the interaction small letters were used. Means followed by the same letters were not significantly different at $5 \%$ level. 


\section{Flesh thickness (cm)}

Tabulated data in Table (8) showed that the addition of magnetic iron either at 1000 or $750 \mathrm{~g}$ per tree were effective in this respect as the two above mentioned levels increased the fruit flesh thickness during both seasons of study. On the other hand, the least value of fruit flesh thickness was detected with control treatment.

In addition, the maximum fruit flesh thickness values of "Aggizi" cultivar grown under salinity stress conditions were detected with higher levels of potassium humate (100 or $75 \mathrm{~g}$ per tree) in both seasons of study.

However, the maximum fruit flesh thickness value was recorded with the combination between magnetic iron at $750 \mathrm{~g}$ per tree and potassium humate at $75 \mathrm{~g}$ per tree. Meanwhile, the least fruit flesh thickness value was recorded with the trees that did not receive any of both factors.

\section{Fruit length (cm)}

Data in Table (9) indicate that all magnetic iron treatments exerted statistically similar effect on fruit length in the first season. While, treated trees with magnetic iron at $1000 \mathrm{~g}$ per tree enhanced obviously the length of fruit in the second season. On the other hand, untreated trees had given the least length of fruit in both seasons.

Moreover, all potassium humate treatments gave a similar and high positive effect on length of fruit in the first season. During the second season, the highest fruit length was recorded with potassium humate at either 100 or $75 \mathrm{~g}$ per tree. While, the control treatment showed the least values in this respect in both seasons.

The combination between the higher levels of magnetic iron and potassium humate (1000 or $750 \mathrm{~g}$ per tree +100 or $75 \mathrm{~g}$ per tree) significantly increased the length of fruit. At the same time, the lowest value of fruit length was recorded with trees that did not receive either agent during the two seasons.

Table (9): Effect of magnetic iron (MI), potassium humate (KH) and their interactions on fruit length and Fruit diameter of "Aggizi "olive trees grown under salt stress conditions in 2017/018 and 2018/019 seasons.

\begin{tabular}{|c|c|c|c|c|c|c|c|c|c|c|}
\hline \multirow{3}{*}{$\begin{array}{l}\text { Magnetic iron } \\
\text { treatments } \\
(\mathrm{g} / \text { tree })\end{array}$} & \multicolumn{5}{|c|}{$2017 / 2018$} & \multicolumn{5}{|c|}{$2018 / 2019$} \\
\hline & \multicolumn{10}{|c|}{ Potassium humate treatments (g/tree) } \\
\hline & $\mathbf{0}$ & 50 & 75 & 100 & Mean & $\mathbf{0}$ & $\mathbf{5 0}$ & 75 & 100 & Mean \\
\hline \multicolumn{11}{|l|}{ Fruit length $(\mathrm{cm})$} \\
\hline $\mathbf{0}$ & $2.12 \mathrm{e}$ & $2.97 \mathrm{abc}$ & 2.86abcd & $2.72 \mathrm{~cd}$ & $2.66 \mathrm{~B}$ & $2.15 \mathrm{bc}$ & $2.29 \mathrm{bc}$ & $2.11 b c$ & $2.31 b c$ & 2.21B \\
\hline 500 & $2.69 \mathrm{~d}$ & $2.84 \mathrm{bcd}$ & $2.95 \mathrm{abcd}$ & $2.93 \mathrm{abcd}$ & 2.85A & $2.32 \mathrm{bc}$ & $2.16 \mathrm{bc}$ & $2.23 \mathrm{bc}$ & $2.30 \mathrm{bc}$ & 2.25B \\
\hline 750 & $2.82 \mathrm{bcd}$ & $2.75 \mathrm{bcd}$ & $3.09 \mathrm{a}$ & 2.88abcd & 2.88A & $2.14 \mathrm{bc}$ & $2.08 \mathrm{c}$ & $2.08 \mathrm{~b}$ & $2.41 b$ & 2.17B \\
\hline 1000 & 2.88abcd & $2.80 \mathrm{bcd}$ & $2.99 \mathrm{ab}$ & $2.99 \mathrm{ab}$ & 2.82A & $2.34 \mathrm{bc}$ & $2.26 \mathrm{bc}$ & $2.81 \mathrm{a}$ & $2.32 \mathrm{a}$ & $2.43 \mathrm{~A}$ \\
\hline Mean & $2.63 \mathrm{~B}$ & $2.84 \mathrm{~A}$ & 2.97A & $2.88 \mathrm{~A}$ & & 2.24B & $2.20 \mathrm{~B}$ & $2.31 \mathrm{~A}$ & 2.33A & \\
\hline \multicolumn{11}{|c|}{ Fruit diameter $(\mathrm{cm})$} \\
\hline 0 & $1.37 \mathrm{~h}$ & $1.63 \mathrm{fg}$ & $1.83 \mathrm{~cd}$ & $1.78 \mathrm{cde}$ & 1.65D & $1.44 \mathrm{ef}$ & $1.46 \mathrm{ef}$ & $1.44 \mathrm{f}$ & $1.78 \mathrm{bcd}$ & 1.53B \\
\hline 500 & $1.58 \mathrm{~g}$ & 1.76de & $1.82 \mathrm{~cd}$ & $1.94 \mathrm{~b}$ & $1.77 \mathrm{C}$ & $1.62 \mathrm{de}$ & $1.73 \mathrm{bcd}$ & $1.72 \mathrm{bcd}$ & $1.83 \mathrm{abc}$ & $1.72 \mathrm{~A}$ \\
\hline 750 & $1.70 \mathrm{ef}$ & $1.77 \mathrm{de}$ & $2.08 \mathrm{a}$ & $1.84 \mathrm{~cd}$ & $1.84 \mathrm{~A}$ & $1.68 \mathrm{~cd}$ & $1.79 \mathrm{bcd}$ & $1.99 \mathrm{a}$ & $1.81 \mathrm{bc}$ & $1.81 \mathrm{~A}$ \\
\hline 1000 & $1.74 \mathrm{de}$ & $1.81 \mathrm{~cd}$ & $1.88 \mathrm{bc}$ & $1.85 \mathrm{bcd}$ & $1.82 B$ & $1.74 \mathrm{bcd}$ & $1.78 \mathrm{bcd}$ & $1.76 \mathrm{bcd}$ & $1.86 \mathrm{ab}$ & 1.79A \\
\hline Mean & $1.60 \mathrm{C}$ & $1.74 \mathrm{~B}$ & $1.90 \mathrm{~A}$ & $1.85 \mathrm{~A}$ & & $1.62 \mathrm{C}$ & 1.69BC & $1.73 B$ & $1.82 \mathrm{~A}$ & \\
\hline
\end{tabular}

Values within column and row for any of two investigated factors were individually differentiated by capital letters, while for the interaction small letters were used. Means followed by the same letters were not significantly different at $5 \%$ level.

\section{Fruit diameter $(\mathbf{c m})$}

Data in Table (9) refer that the higher dose $750 \mathrm{~g}$ per tree of magnetic iron recorded the maximum of average fruit width, followed by magnetic iron dose at $1000 \mathrm{~g}$ per tree, as compared with untreated trees that reflect the least value of the investigated parameter in both seasons.

Furthermore, the maximum fruit width was obtained by applying potassium humate at $75 \mathrm{~g}$ per tree, followed by $100 \mathrm{~g}$ per tree in the first season, and the reverse was true in the second season. While, the lowest fruit width was obtained with the control treatment in both seasons of study.

In addition, magnetic iron at $750 \mathrm{~g}$ per tree combined with $75 \mathrm{~g}$ per tree of potassium humate induced highly significant improvement in the average fruit width in both seasons. On the other way around, the least value of average fruit width was recorded with the trees that were not received any of the two investigated anti-salt stress substances.

\section{Discussion}

The ultimate goal of the health and vigour management of tree through integrated approaches is to improve flowering, fruit setting and yield. In addition, fruit weight, fruit size and flesh thickness are the most important parameters and are mainly considered when fruits are bought for a Table olive use.

Application of magnetite and K-humate to saline soils results in reduction in the concentration of sodium salts which is not correlated with a leaching of the salt, yet it may be correlated with improving the root growth and accumulation of $\mathrm{Na}^{+}$in the root and less $\mathrm{Na}^{+}$transduction to plant aerial parts. This effect enhances root absorption, decreases salinity, increases 
in soil organic matter content and improves the balance of endogenous hormones, which has contributed to improved plant nutrient status and photosynthesis, reflecting plant growth and productivity (Cimrin et al., 2010; Aydin et al., 2012; Abobatta, 2015; Javanshah and Aminian-Nasab, 2016). Also, an increasing in photosynthetic rate, a positive effect as a result of magnetic which leads to a better photo stimulation (Hoff, 1981).

Humic acid increases plant growth and production by increasing protein synthesis (Russo and Berlyn, 1990; Delfine et al., 2005). The reduced photosynthetic ability under salinity is due to stomata closure and suppression of specific enzymes that are responsible for the synthesis of photosynthetic pigments. Humic acid increased the antioxidant enzymes activity and caused the plant to absorb different nutrient elements, especially $\mathrm{K}$, which is a major element in the synthesis of proteins and enzymes, and it was effective in coping with salinity stress and improving photosynthesis by helping the stomata to open more (Mahmoudi et al., 2014).

Potassium humate was combined with magnetic iron to increase effective adsorption sites and hydroxyl groups showed a considerable adsorption capacity of $280.6 \mathrm{mg} / \mathrm{g}$. Metal oxide/carbon composites especially ferric oxide/carbon films, have special features such as functional surface, porous structure, large surface area and special separation properties under external magnetic field (Lei, et al., 2014; Gu et al., 2016).

The results reported herein regarding the impact of magnetic iron and potassium humate on flowering of "Aggizi " olive trees were very similar to those reported by Lovatt et al., (1988); Ahmed et al.,(2011); Khattab et al., (2012); Sugier et al.,(2013) and Ahmad et al.,(2013) they found that, positive associations between accumulations of carbohydrates and flowering have been shown. The application of humic acid will increase the number of pomegranate flowers. Humic acid application increased spike length, which confirmed the role of HA in improving nutrient uptake, and in turn increased spike length and overall flower quality. The flowering stage of Rosella plants was earlier when the soil was blended with magnetic iron plus humic acid and enhanced the number of open flowers per plant.

Generally, fruit set percentage, fruit drop ratio and trees production results of this study are in line with the results obtained by Abdel-Aziz et al., (2010); Du et al., (2011) and Mohamed et al., (2013). It is also interesting to note that the apparently reduced accumulation of $\mathrm{Na}$ in plants with magnetite and humate treatments may have helped the trees to continue their growth with less detrimental effects on total yield (Eman et al., 2010; Abobatta, 2015). Soil application of NEC (natural element compound) including magnetite on navel orange trees improved tree yield through increasing fruit set $\%$ and reducing the pre-harvest fruit drop percentage (Abd El-
Rahman et al., 2015; Ibrahim, 2011). Humic acid improved fruit yield and decreased the percentage of fruit drop in 'Anna' apple (Mosa et al., 2015).

Likes wise, Eman et al., (2010) reported that the highest yield of le conte pear trees was obtained when the trees were received 750 and $1000 \mathrm{~g} /$ tree of magnetic iron. Meanwhile, Ismail et al., (2010) on grapevine and Ali, Mervat et al., (2013) on Thompson seedless grapevines cleared that magnetic iron was the superior one in enhancing vine yield as expressed as weight and number of cluster/vine in comparison with vines under salinity stress condition. Moreover, Alva and Obreza (1998) reported that, application of iron humate increased fruit yield of Hamlin orange trees. Moreover, the explanation for obtaining highest percentage of fruit oil with magnetite plus humic may be due to their effect on plant growth stimulation through increased photosynthetic and carbohydrate content, as well as improved nutrient and water absorption, hormonal regulation, improved plant growth and increased stress tolerance (Zaghloul et al., 2009; Laila et al., 2013).

The increase in fruit weight, fruit size, fruit length and diameter in many species due to magnetite and khumate application is probably ascribed to improve the absorption of mineral nutrients under salt stress conditions. However, the possible hormone- like activity of the humic acid (i.e., auxin-, gibberellin and cytokinin-like activity), should also be taken into consideration (El-zaawely et al., 2013; Abobatta, 2015). Increased CK with IAA could result in increased photosynthetic pigments, vegetative growth, fruit yield and fruit quality of 'Chemlali' olive trees (Dabbaghi et al., 2018). Humic substances increase the tolerance of plants to abiotic stress through the regulatory effect on phytohormone levels, in particular ABA (Cimrin et al., 2010). Humic acid hormone-like effect, particularly IAA, has been documented on fruit weight and dimensions, in 'Florida Prince' peach (Abd El-Razek et al., 2012) and 'Kalamata' olive (Laila et al., 2013). Humic acid at $1 \%$ recorded maximum custard apple fruit yield per plant, fruit weight and diameter (Sindha et al., 2018). The increase in fruit weight may be due to the stimulation of photosynthetic pigment accumulation and photosynthesis rate (Abdel-Mawgoud et al., 2007)

Referring to the relationship between magnetic Iron and fruit quality, the present results are in line with those reported by Mohamed et al., (2013) and Abobatta (2015) on Valencia orange trees, as they reported that magnetite increased fruit dimension, peel thickness and fruits had good rind color. In the same line, Ismail et al., (2010) found that magnetic Iron was more effective in achieving the best value of berry characteristics (weight, volume, length and diameter).

\section{Conclusion}

Based on the results obtained, the soil application of magnetic iron and/or potassium humate could 
significantly improve the flowering and fruiting characteristics of 'Aggizi' olive trees affected by salinity.

\section{References}

Abadía, J., Morales, F. Abadía, A., 1999. Photosystem II efficiency in low chlorophyll, iron-deficient leaves. Plant Soil. 215(2), 183-192.

Abd El-Rahman, M.M.A., 2015. Relation of Spraying Silicon with Fruiting of Kiette Mango Trees Growing Under Upper Egypt Conditions. Stem Cell. 6(2), 1-5.

Abdel-Aziz, R. A., Nady, N. H. Pasqualon, A., 2010. The effect of some organic fertilization types on tree growth and fruit quality of Eureka lemon under newly reclaimed lands in Toshka. Egypt. J. of Appl. Sci., 25 (2b), 66-84.

Abdel-Mawgoud, A.M.R., El-Greadly, N., Helmy, Y.I. Singer, S.M., 2007. Response of tomato plants to different rates of humic based fertilizer and NPK fertilization J. Appl. Sci. Res. 3, $169-$ 174

Abobatta, W.F., 2015. Influence of magnetic iron and $\mathrm{K}$-humate on productivity on Valencia Orange trees (Citrus Sinensis L.) under Salinity Conditions. Int. J. Scient. Res. Agric. Sci. 2, 108119.

Ahmad, I., Usman Saquib, R., Qasim, M., Saleem, M., Sattar Khan, A., Yaseen, M., 2013. Humic acid and cultivar effects on growth, yield, vase life, and corm characteristics of gladiolus. Chil. J. Agric. Res. 73(4), 339-344.

Ahmed, M. A., Ali, S. M., El-Dek, S. I. Galal, A., 2013. Magnetite--hematite nanoparticles prepared by green methods for heavy metal ions removal from water. Mater. Sci. Eng. B, 178(10), 744-751.

Ahmed, M.Y., Shalaby, E. A. and Shanan, Nermeen, T., 2011. The use of organic and inorganic cultures in improving vegetative growth, yield characters and antioxidant activity of roselle plants (Hibiscus sabdariffa L.). Afr. J. Biotechnol. 10(11), 1988-1996.

Aladjadjian, A., 2002. Study of the influence of magnetic field on some biological characteristics of Zea mais. J. Cent. Eur. Agric. 3 (2), 89-94.

Ali, Mervat, A., El-Gendy, S. S. R. Ahmed, Ola, A., 2013. Minimizing adverse effects of salinity in vineyards. J. Hort. Sci. Ornamen. Plants. 5 (1), 1221

Alva, A. K. and Syvertsen, J. P., 1991. Soil and citrus tree nutrition are affected by salinized irrigation water. proc. fla. state hort. soc. 104, 135138.

AOAC (1990) Official methods of analysis of the Association of Official Analytical Chemists, vol II, 15th edn. Sec. 985.29. The Association, Arlington, VA, USA.

Aydin, A., 2011. Effects of cluster reduction, herbagreen and humic acid applications on grape yield and quality of Horoz Karasi and Gök üzüm grape cultivars. Afr. J. Biotechnol. 10(29), 55935600.

Bahn, A. N., Dirks, O. B., Destoppelaar, J. D., Huisintveld, J. H. J., Boom, A., Hayashi, J. A., 1979. Function of neuraminidases from oral Streptococci and Actinomycetes in the plaqueformation. Caries Res. 13, 86-87

Bartolini Bussi, M., 1991. Social interaction and mathematical knowledge. In Proceedings of the fifteenth annual conference of the international group for the psychology of mathematics education (Vol. 1, pp. 1-16).

Belkhodja, R., Morales, F., Abadia, A., GomezAparisi, J. Abadia, J., 1994. Chlorophyll fluorescence as a possible tool for salinity tolerance screening in barley (Hordeum vulgare L.). Plant Physiol. 104(2), 667-673.

Caponera, D., 1993. Legal aspects of transboundary river basins in the Middle East: The Al Asi (Asi), the Jordan and the Nile. Nat. Resour. J. 28(3), 629663.

Chartzoulakis, K., Loupassaki, M., Bertaki, M., Androulakis, I., 2002. Effects of $\mathrm{NaCl}$ salinity on growth, ion content and $\mathrm{CO} 2$ assimilation rate of six olive cultivars. Sci. Hortic. 96, 235-247.

Cimrin, K.M., Onder, T., Turan, M., Burcu, T., 2010. Phosphorus and humic acid application alleviate salinity stress of pepper seedling. J. Afric. Biotech. 9, 5845-5851.

Dabbaghi, O., Tekaya, M., Öden, S., Willems, T., Attia, F., Hammami, M., Mechri, B., 2018. Foliar application of bio-fertilizers influenced the endogenous concentrations of phytohormones and amino acids in leaves and roots of olive trees (Olea europaea L. cv. Chemlali). Afr. J. Agric. Res. 13 (34), 1777-1786.

Delfine, S., Tognetti, R., Desiderio, E. Alvino, A., 2005. Effect of foliar application of $\mathrm{N}$ and humic acids on growth and yield of durum wheat. Agron Sustain Dev, 25, 183-191

Du, Z. H: Fan, H.K: Lü, Z.F. Wu. D.Y., 2011. Effects of fertilization regime on growth, yield and quality of Fuji apple in Weibei highland. Acta Agri. Boreali - Occident. Sin. 20, 15-23.

Duncan, D. B., 1955. Multiple range and multiple F tests. Biometrics. 11(1), 1-42.

El-Hefny, E. M., 2010. Effect of saline irrigation water and humic acid application on growth and productivity of two cultivars of cowpea (Vigna unguiculata L. Walp). Aust. J. Basic Appl. Sci. 4(12), 6154-6168.

El-Razek, E. A., Abd-Allah, A. S. E., Saleh, M. M. S., 2012. Yield and fruit quality of Florida Prince peach trees as affected by foliar and soil applications of humic acid. J. Appl. Sci. Res. 8(12), 5724- 5729.

El-zaawely, A. A., Ahmed, M. E. M., Bayoumi, Y. A., 2013. Effect of magnetic field on seed germination, growth and yield of sweet pepper 
(Capiscum annum L.). Asian J. Crop Sci. 5 (3), 286-294.

Eman, S. A., Abd El-Messeih, M. W. Mikhael, B. G., 2010. Using of natural raw material mixture and magnetite raw (magnetic iron) as substitute for chemical fertilizers in feeding "Le Conte" Pear trees. Alex. Sci. Exchange J. 31(1), 51-62.

Flowers, T. J., Galal, H. K. Bromham, L., 2010. Evolution of halophytes: multiple origins of salt tolerance in land plants. Funct. Plant Biol. 37(7), 604-612.

Gad El-Hak, S. H., Ahmed, A. M. Mostafa, Y. M. M., 2012. Effect of foliar application with two antioxidants and humic acid on growth, yield and yield components of peas (Pisum sativum L.). J. Hortic. Sci. Ornamen. Plant. 4(3), 318- 328.

Grattan, S. R. Grieve, C. M., 1999. Mineral nutrient acquisition and response by plants grown in saline environments. Handbook of plant and crop stress. 2, 203-229.

Gu, H., Lou, H., Ling, D., Xiang, B. Guo, Z., 2016. Polystyrene controlled growth of zerovalent nanoiron/magnetite on a sponge-like carbon matrix towards effective $\mathrm{Cr}$ (VI) removal from polluted water. RSC advances. 6(111), 110134110145.

Hoda, M. M., Faten, A. K. Azza, A. M. A., 2013. Effect of magnetite and some biofertilizers application on growth and yield of Valencia orange trees under El-Bustan condition. J. Nat. Sci. 11(6), $46-61$.

Hoff, A. J., 1981. Magnetic field effects on photosynthetic reaction. Quat Rev Biophys. 14(4), 599- 665 .

Ibrahim, Y. M., 2011. Optimum use of geological raw materials in industry and their environmental impact. Ph. D. Thesis. Fac. of Sci. Mansoura Univ.

Illés, E., Tombácz, E., 2006. The effect of humic acid adsorption on $\mathrm{pH}$ dependent surface charging and aggregation of magnetite nanoparticles. J. Colloid Interface Sci. 295, 115-123.

Ismail, A. E., Soliman, S. S., Abd-El-Moniem, E. M., Awad, M. S. Rashad-Azza, A., 2010. Effect of magnetic iron ore, metal compound fertilizer and bio-NK in controlling root -rot nematode of grapevine in a newly reclaimed area of Egypt. Pak. J. Nematol. 28 (2), 307-328.

Javansha, A., Aminian Nsab, S., 2016. The effects of humic acid and calcium on morphophysiological traits and mineral nutrient uptake of pistachio seedling under salinity stress. J. Nuts. 7 (2), 125-135.

Jenkinson, D.S. Ladd, J.N., 1981. Microbial biomass in soil: measurement and turnover. In: Soil

Marin, S., Sanchis, V., Vinas, I., Canela, R., Magan, N., 1995. Effect of water activity and temperature on growth and fumonisin B1 and B2 production by Fusarium proliferatum and $\mathrm{F}$.
Biochemistry (eds E. A. Paul and J. N. Ladd), pp. 415-471. Marcel Dekker, New York.

Karajeh, F., Oweis, T., Swelam, A., El-Gindy, A., El-Quosy, D., Khalifa, H., El-Kholy, M., ElHafez, S. A., 2011. Water and agriculture in Egypt. Technical paper based on the EgyptAustralia-ICARDA Workshop On-farm Wateruse Efficiency. Egypt: International Center for Agricultural Research in the Dry Areas (ICARDA).

Khattab- Magda, M., Shaban, E. A., El-Sherif, H. A. and S. El- Deen, A. M., 2012. Effect of humic acid and amino acids on pomegranate trees under deficit irrigation. I: growth, flowering and fruiting. J. Hort. Sci. and Ornamen. Plants. 4(3), 253-259.

Kirn, A, S.R. Kashif, M. Yaseen., 2010. Using indigenous Humic from lignite to increase growth and yield of okra (Abelmoschus esculentus L.). Soil Environ. 29(2), 187-191.

Laila, F. H., Shahin, M. F. M., Merwad, M. A., Khalil, F. H. El-Hady, E. S., 2013. Improving fruit quality and quantity of "Aggizi" olive trees by application of humic acid during full bloom and fruit set stages. Middle East j. 2(2), 44-50.

Laila, F. H., Shahin, M. F. M., Mustafa, N. S., Merwad, M. A., Khalil, F. H., 2013. Influence of using humic acid during full bloom and fruit set stages on productivity and fruit quality of" Kalamata" olive trees. J. Appl. Sci. Res. 9(3), 2287-2292.

Lei, Y., Chen, F., Luo, Y. Zhang, L., 2014. Threedimensional magnetic graphene oxide foam $/ \mathrm{Fe} 3$ O 4 nanocomposite as an efficient absorbent for $\mathrm{Cr}$ (VI) removal. J. Mater. Sci. 49(12), 4236-4245.

Long, S.P., Baker, N.R., 1986. Saline terrestrial environments. In: Baker, N.R., Long, S.P. (Eds.), Photosynthesis in Contrasting Environments. Elsevier, Amsterdam. pp. 63-102.

Lovatt, C. J., Zheng, Y. and Hake, K. D., 1988. Demonstration of a change in nitrogen metabolism influencing flower initiation in Citrus. Isr. J. Bot. 37, 181-188.

Mahmood, K., 2011. Salinity tolerance in barley (Hordeum vulgare L.): effects of varying $\mathrm{NaCl}$, $\mathrm{K}$ ?/Na? and $\mathrm{NaHCO}_{3}$ levels on cultivars differing in tolerance. Pak. J. Bot. 43(3), 1651-1654.

Mahmoudi, M., Samavat, S., Mostafavi, M., Khalighi, A., Cherati, A., 2014. The effect of humic acid and proline on morphological properties of Actinidia deliciosa cv. Hayward under salinity. J. Appl. Sci. Agric. 9 (1), 261-267.

Mansour, S. F., 2011. Structural and magnetic investigations of sub-nano $\mathrm{Mn}-\mathrm{Mg}$ ferrite prepared by wet method. J. Magn. Magn. Mater. 323(13), 1735-1740.

moniliforme on maize grain. Lett. Appl. Microbiol. 21(5), 298-301.

Mengel, K. Kirkby, E. A: Kosegarten, H., and Appel, T., 2001. Nitrogen. In Principles of plant nutrition (pp. 397-434). Springer, Dordrecht. 
Morales, F., Abadía, A. AbadPa, J., 2008. Photoinhibition and photoprotection under nutrient deficiencies, drought and salinity. In Photoprotection, photoinhibition, gene regulation, and environment (pp. 65-85). Springer, Dordrecht.

Mosa, W. F. A. E. G., Abd EL-Megeed, N. A., Paszt, L. S., 2015. The effect of the foliar application of potassium, calcium, boron and humic acid on vegetative growth, fruit set, leaf mineral, yield and fruit quality of 'Anna' apple trees. J. Exp. Agric. Int. 224-234.

Rallo, L., Diez, C. M., Morales-Sillero, A., Miho, H., Priego-Capote, F. Rallo, P., 2018. Quality of olives: A focus on agricultural preharvest factors. Sci. Hortic. 233, 491-509.

Rapoport, H. F., and Rallo, L., 1991. Posta thesis flower and fruit abscission in manzanillo 'Olive. J. Am. Soc. Hortic. Sci. 116(4), 720-723.

Russo, R.O., Beryln, G.P., 1990. The use of organic biostimulants to help lowinputs. j. sustain. agric. 1, 19-42.

Sindha, D.J., Satodiya, B.N. Sutariya, N.K., 2018. Effect of foliar application of different chemicals and humic acid on fruit yield and quality of custard apple (Annona squamosal L.) cv. Local Intl. J. Chem. Studies. 6(5), $1026-1037$
Snedecor, G. W. and Cochram, W.G., 1980. Comparisons of two samples In: Snedecor and Cochran (ed) Statistical Methods.

Sugier, D., Kołodziej, B., Bielińska, E., 2013. The effect of leonardite application on Arnica montana L. yielding and chosen chemical properties and enzymatic activity of the soil. J. Geochem. Explor. 129, 76-81.

Tattini, M., Gucci, R., Coradeschi, M. A., Ponzio, C., and Everard, J. D., 1995. Growth, gas exchange and ion content in Olea europaea plants during salinity stress and subsequent relief. Physiol. Plant. 95(2), 203-210.

Vigo, C., Therios, I.N., Bosabalidis, M., 2005. Plant growth, nutrient concentration, and leaf anatomy of olive plants irrigated with diluted seawater. J. Plant Nutr. 28, 1001-1021.

Vigo, C., Therios, I.N., Patakas, A., Karatassou, M., Nastou, A., 2002. Changes in photosynthetic parameters and nutrient distribution of olive plants (Olea europaea L.) cultivar "Chrondolia Chakidiskis" under $\mathrm{NaCl}, \mathrm{Na} 2 \mathrm{SO} 4$ and $\mathrm{KCl}$ salinities. Agrochimica. 46, 33-46.

Zaghloul, S. M., El-Quesni, F. E. M., Mazhar, A. A. M., 2009. Influence of potassium humate on growth and chemical constituents of Thuja orientalis L. seedlings. Ozean J. Applied Sci. 2, 73-78.

$$
\begin{aligned}
& \text { تأثير الحديد المغتاطيسي وهيومات البوتاسيوم علي بعض الصفات الزهزيه والثمريه لأثجار الزيتون العجيزى التاميه } \\
& \text { تحت ظروف الإجهاد الملحي بجنوب سيناء } \\
& \text { محمد جمعه محمد أبوجبين" } \\
& \text { - صابر محمود محمد بكير } 1 \text { - }
\end{aligned}
$$

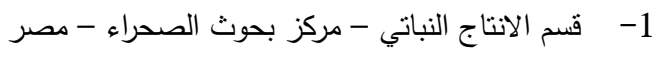

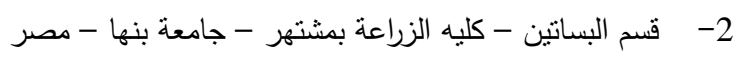

يعد استخدام محسنات التربة طريقة فسيولوجية مهمة تعمل على تحسين تحمل النبات للإجهاد الملحي. الهدف من هذا البحث هو دراسة إضافة

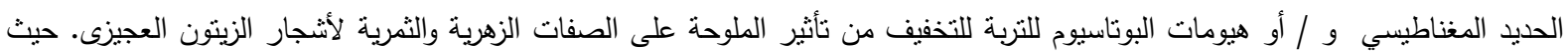
تمت معاملة الأشجار التي يبلغ عمرها عشر سنوات والمزروعة في نربة طينية رملية بأربعة مستويات من كل من الحديد المغناطيسى (صفر ,500,

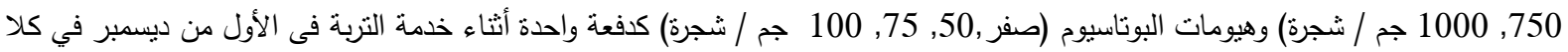

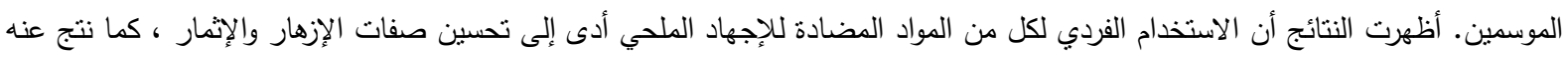

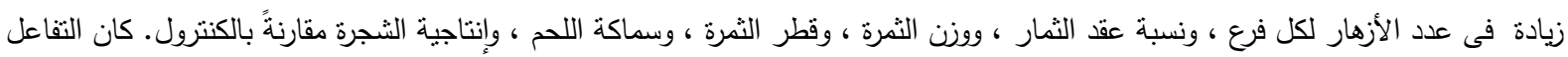
المشترك بين الحديد المغناطيسى وهيومات البوتاسيوم معنويا لجميع الصفات المدروسة. حيث أدى تفاعل المعدلات الأعلى من كل من الدئ الحديد المغناطيسى (1000 أو 750جم/شجرة) وهيومات البوتاسيوم (100 أو 75جم/شجرة) إلى تحسين الخصائص الزهرية والثمرية لأشجار الزينتون

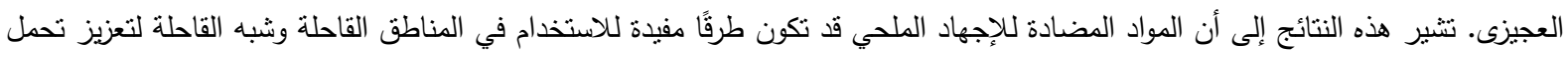
الملوحة في الزيتون. 